Jpn. J. Limnol., 59 : 383-389, 1998

\title{
Immature Stages of Lenarchus fuscostramineus SCHMID (Trichoptera, Limnephilidae)
}

\author{
Takao NozAKI and Tomiko ITo
}

\begin{abstract}
The larva and the pupa of Lenarchus fuscostramineus ScHmid are described here for the first time. The general morphology of the larva mostly agrees with the character of the genus provided based on North American species by WigGins (1977). The larvae live in small shallow springs and seeping areas and feed on highly decomposed plant material. We established that the larvae described as Lenarchus sp. LA from Honshu by TANIDA (1985) were a misidentification of Nothopsyche sp. NA.
\end{abstract}

Key words : Trichoptera, Lenarchus fuscostramineus, larva, pupa, case

\section{INTRODUCTION}

Lenarchus SCHMID is a Holarctic genus with 13 species occurring throughout the northern part of the region (SCHMID, 1955). However, our knowledge of its immature stages is quite poor. WIGGINs (1977) provided the larval diagnostic characteristics of this genus for the first time based on North American species, and illustrated the larva and the case of Lenarchus vastus (HAGEN). SolEm and GULLEFors (1996) adopted some of the characteristics for North European Lenarchus in their key to the genera. In Japan, only one species, Lenarchus fuscostramineus ScHMID, 1952, is known from Nemuro, Tokachi and Ishikari in Hokkaido (SCHMID, 1952; ITOU et al., 1993). On the other hand, TANIDA (1985) described a larva as Lenarchus sp. LA from Honshu. However, until now neither the immature stages of $L$. fuscostramineus nor the adults of Lenarchus sp. LA have been known.

In this paper, we describe the larva and the pupa of $L$. fuscostramineus for the first time based on material reared by Mr. Kawamula of the Hokkaido Fish Hatchery, and the junior author. In addition, we show that the larva described as Lenarchus sp. LA does not belong to the genus Lenarchus based on an examination of the material which was used for the description by TANIDA (1985). Morphological terms used in this paper follow WigGins $(1977,1996)$. Immature stages were associated with the adult by rearing larvae to adults. Specimens used are deposited in the collection of the Natural History Museum and Institute, Chiba (CBM) and in the personal collections of the authors (TN and TI). 
Lenarchus fuscostramineus ScHMID, 1952

[Japanese name : Kurozu-eguri-tobikera]

Lenarchus fuscostramineus ScHмID, 1952, 207-210 ; IтоU et al., 1993, 3 ; Niммо et al., 1997, 119 ; Iто et al., 1998, 11.

Limnephilus borealis ZETTERSTEDT : KuWAYAMA, 1932, 1505. Misidentification established by NOZAKI and TANIDA (1996).

\section{(Figs. 1, 2)}

Final instar larva (Fig. 1). Length of larva up to $13 \mathrm{~mm}$. Head (Fig. 1b) dark brown with slightly lighter muscle scars on the posterior part ; primary setae nos. $1,4,6,10,11,13,16$ and 18 transparent ; seta no. 14 longest; seta no. 18 minute. Ventral apotome (Fig. 1f) vase-shaped. Labrum (Fig. 1d) with anterolateral margin completely sclerotized. Mandibles (Fig. 1e) black, triangular in dorsal aspect, right and left symmetrical with five apical teeth.

Pronotum (Fig. 1c) dark brown with slightly darker muscle scars, strongly constricted at the posterior margin and weakly depressed at one-third distance from the anterior margin which is covered with transparent secondary setae. Mesonotum (Fig. 1c) mostly brown, posterior margin darker brown ; setal areas usually separated, but occasionally one short seta arising between sa1 and sa2. All metanotal setae (Fig. 1c) arise on three primary sclerites : 6 to 10 on sa 1,9 to 12 on sa2 and 15 to 19 on sa3.

Legs (Fig. 1i) brown without distinct marking or bands, foreleg shortest. Femora of middle and hind legs with two major setae along ventral edge.

In first abdominal segment (Fig. 1g, h), setal areas separated; setae on dorsum scarce : 4 to 6 on sa 1,4 to 8 on sa2, 6 to 9 on sa 3 ; setae on venter scarce : 5 to 11 on sa1, 4 to 9 on sa2, 4 to 8 on sa3 ; lateral hump bearing 1 seta on antero-ventral base. Most abdominal gills (Fig. 1a) with more than four branches (some with more than 10 branches) present on following segments : dorsal gills on 2nd to 7th (anterior and posterior) and usually on 8 th (anterior) ; ventral gills on 2nd to 7th (anterior and posterior) ; lateral gills on 2nd (posterior) and 3rd (anterior). Lateral fringe extending from 3rd to 8th abdominal segments. Forked lamellae present on each side of 3rd to 8th abdominal segments. Chloride epithelia (Fig. 1a) present on following abdominal segments : 2nd (dorsal and ventral), 3rd to 7th (dorsal, lateral and ventral), 8th (dorsal). Dorsal sclerite of 9th abdominal segment bears 14-17 setae. Basal tuft (Fig. 1j) with three long setae, mesal two setae longer than outer one. Anal claw (Fig. 1j) bears an accessory hook.

Pupa (Fig. 2). Length up to $13 \mathrm{~mm}$. Antenna same length as body in male, slightly shorter in female ; ventrolateral and dorsal tufts of setae (Fig. 2a) present on first and second segments, respectively. Labrum (Fig. 2a) with 6 pairs of setae on dorsum, 3 pairs of longer ones curved at apices. Mandibles (Fig. 2b) thick at the base and acute at the apex ; mesal margins slightly concaved, with numerous fine teeth on apical blade. Middle and hind tarci (Fig. 2f) with sparse setae.

First abdominal segment (Fig. 2e) with a pair of spined ridges. Hook plates (Figs. 2c, d, e) present on anterior parts of 3rd to 7th abdominal 

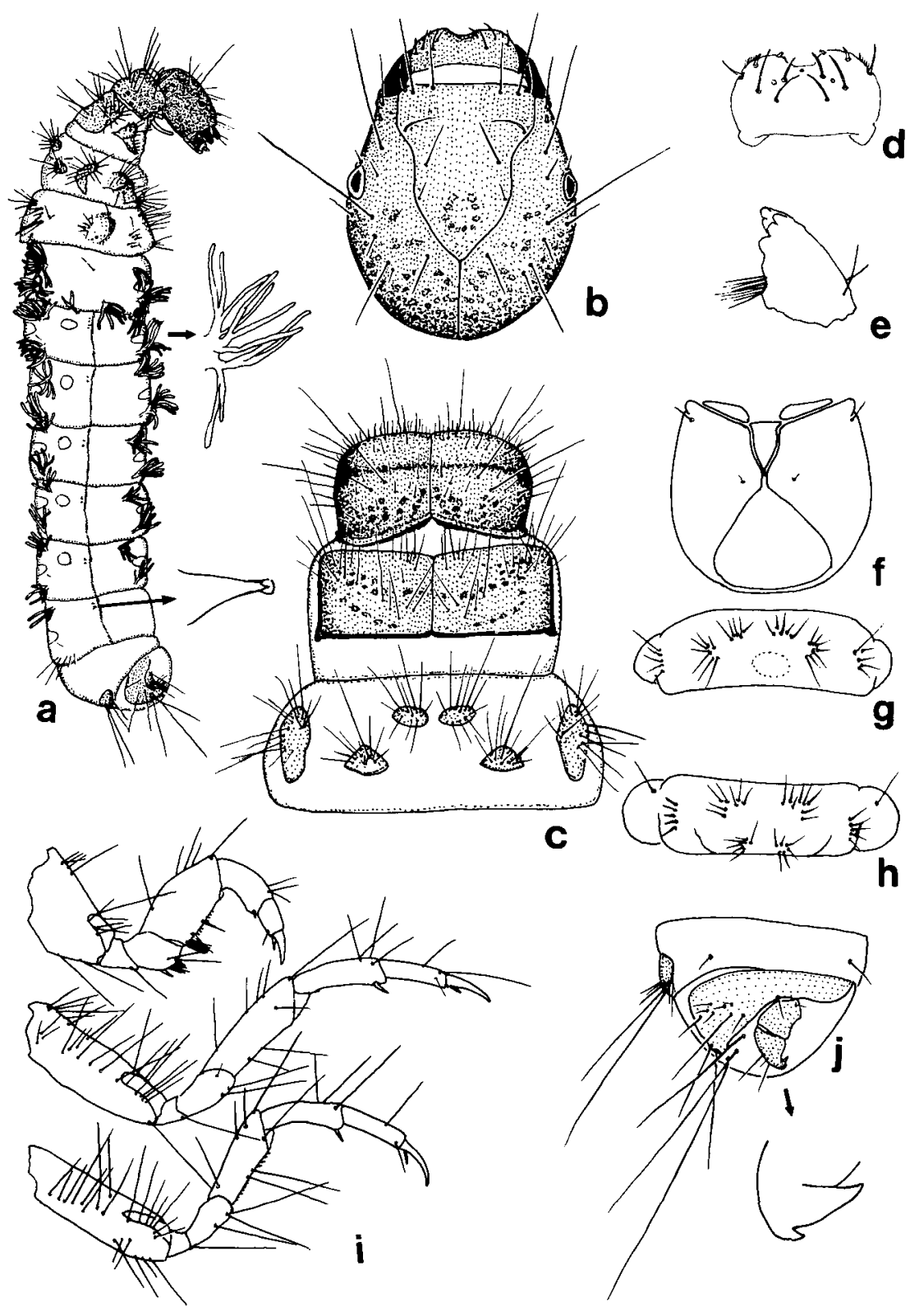

Fig. 1. Final instar larva of Lenarchus fuscostramineus Schmid. a, Lateral ; b, head, dorsal ; c, pro-, meso- and metanota, dorsal ; d, labrum, dorsal ; e, right mandible, dorsal ; f, head, ventral ; g, first abdominal segment, dorsal ; h, same, ventral ; $i$, right legs, lateral ; $j$, ninth abdominal segment and anal proleg, lateral. 

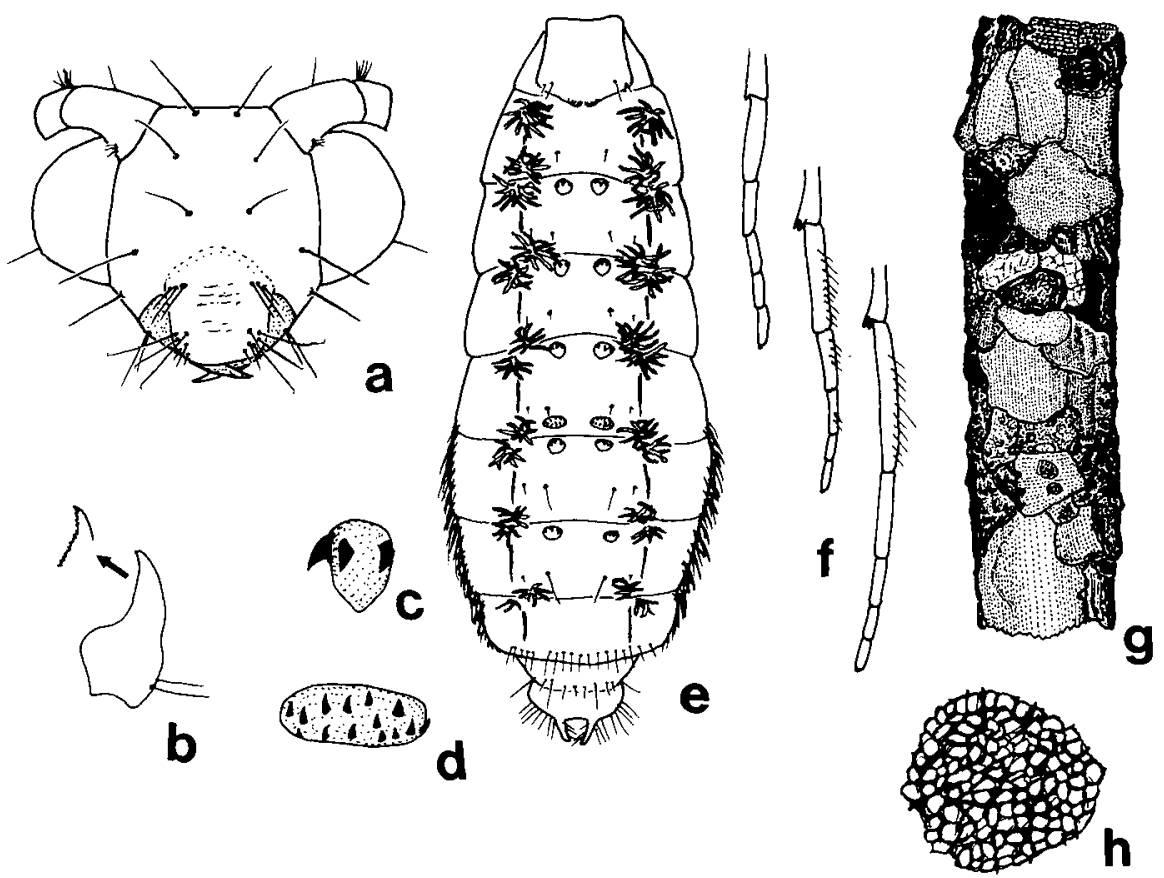

Fig. 2. Pupa and case of Lenarchus fuscostramineus Schmid. a, Pupa (male), frontal ; $b$, right mandible, dorsal ; $c$, hook-plate on the anterior dorsum of 5 th abdominal segment ; $d$, same on posterior dorsum of 5 th abdominal segment ; e, abdominal segments, dorsal ; f, right tarci, mesal ; $g$, case of final instar larva ; h, anterior end of pupal case.

segments and on posterior part of 5th ; anterior plates with 2 to 6 hooks and posterior ones with 8 to 18 hooks. Most abdominal gills (Fig. 2e) have more than four branches present on following segments : dorsal gills on 2nd to 7 th (anterior and posterior) and 8th (usually anterior) ; ventral gills on 2nd to 7th (anterior and posterior) ; lateral gills on 2nd (posterior) and 3rd (anterior). Lateral fringe (Fig. 2e) extending from posterior part of 5th to posterior part of 8th abdominal segment. A pair of anal processes (Fig. 2e) fairly short.

Case (Figs. 2g, h). Cases of final instar larva up to $15 \mathrm{~mm}$ long; constructed of small pieces of leaves and bark, cylindrical, almost straight; posterior opening not closed. Both anterior and posterior ends of pupal case closed by silken sieve membranes and small pieces of plant material.

Specimens examined. Hokkaido: 1 female, 1 larva, a small spring, Hombetsu-cho, larva collected on 29 May 1981, emerged and fixed in June-July 1981, reared by H. Kawamula (TN) ; 3 males, 1 female, 8 larvae, 6 prepupae, 6 pupae, a seeping area, Mita, Hamamasu-mura, larvae collected 23-29 May 1981, fixed on 19 May to 13 June 1981, reared by T. Iто (CBM-ZI 76628-76651) ; 9 larvae, a small spring flow near Lake Rausu, Rausu-cho, 9 October 1995, T. Iто \& A. OHKaWA (TN) ; 3 females, Po-gawa- 
bashi, Po River, Shibetsu-cho, 10 September 1995, T. Iто (TN) ; 5 females, ibid., 12 August 1996, T. Iто and A. OhкаWA (TI) ; 4 females, a spring near Po River, Shibetsu-cho, 12 August 1996, T. ITo and A. Ohkawa (TI) ; 1 larva, a seeping area beside a small stream in Po-gawa Park, Shibetsu-cho, 22 September 1996, T. NozAKI (TN) ; 1 male, Chishine-bashi, Ichani-gawa, Shibetsu-cho, 12 August, 1996, T. Iтo and A. OHKaWA (TI); 2 males, Futatsuyama, Shibecha-cho, 18 July 1989, K. IIJIMA (TN); 1 male, ibid., 9 July 1992, K. IıJIMA (TN); 1 female, Iwabuchi-zawa, Ken'ichi-gawa, Kumaishi-cho, 10-20 July 1995, Y. Іто \& T. Iто (TN); 1 female, ibid., 26 June to 1 July 1995, Y. Iто \& T. Iто (TI) ; 20 larvae, a small spring near Bibi-bashi, Bibi River, Chitose, 8 April 1998, T. Iто (TI).

Distribution. Hokkaido (Nemuro, Kushiro, Tokachi, Ishikari, Hiyama), Iturup, Kunashir.

Habitat. Larvae of $L$. fuscostramineus were collected from small shallow springs and seeping areas beside small streams and marshes. The maximum size of the habitats observed by us is about $50 \mathrm{~cm}$ in width, $1 \mathrm{~cm}$ in depth and $5 \mathrm{~m}$ in length. The water flows slowly (about $5 \mathrm{~cm} \mathrm{sec}^{-1}$ maximum), and the bottoms are covered with small pieces of well decomposed plant detritus. Larvae of North American species inhabit standing waters, edges of small lakes, ponds, marshes and temporaly pools (WINTERBOURN, 1971 ; WIGGINs, 1977).

Food. In laboratory observation, the larvae feed on highly decomposed plant material. Furthermore, the foreguts of three larvae (two from a small spring near Bibi River, Chitose, and one from a seeping area in Po-gawa Park, Shibetsu) were filled with fine particulate organic material including vascular plant fragments. Thus the larvae of $L$. fuscostramineus must feed on well-decomposed plant detritus which is abundant in their habitat. The larvae of a North American species, L. vastus, also feed on organic sediments (WINTERBOURN, 1971).

Remarks. WigGnNs (1977) provided the following diagnostic characteristics of larvae of Lenarchus: (1) most abdominal gills of the dorsal and ventral rows have more than four branches, (2) two major setae present on the ventral edges of the middle and hind legs, (3) all metanotal setae arise on primary sclerites, (4) mesonotal setal areas are separate from each other. SOLEM and GulLEFors (1996) use characteristics of (1) and (2) for their key of North European limnephilid genera. The larvae of $L$. fuscostramineus mostly agree with the characteristics provided by WIGGINs (1977), though some larvae have a short seta between mesonotal setal areas 1 and 2 .

\section{A larva recorded as Lenarchus sp. LA from Honshu}

TANIDA (1985) described a larva as Lenarchus sp. LA from Honshu. We examined two specimens which were used for his description and found that they do not belong to the genus Lenarchus. Although the specimens bear abdominal gills most of which have more than four branches like the larvae of Lenarchus, they have four or more major setae on the ventral edges of the middle and hind femora. Among Japanese genera of Limnephilidae, those 
characteristics are only found in the larvae of Nothopsyche (TANIDA, 1985 ; NoZAKI, unpublished). We identified them as the same species as Nothopsyche sp. NA (TANIDA, 1985) based on the arrangements of abdominal gills and chloride epithelia, though their heads are uniformly black without the characteristic marking of Nothopsyche sp. NA. Thus, there is still no reliable record of Lenarchus species being distributed on Honshu.

Specimens examined. Honshu: 2 larvae, Ushikubi, Kami-ohori, Oze, Gumma, 7 July 1978, K. TANIDA leg.

\section{ACKNOWLEDGMENTS}

We express our cordial thanks to Mr. H. Kawamula, Hokkaido Fish Hatchery, for the gift of the larva of $L$. fuscostramineus which was associated with the adult and to Prof. K. TANIDA, Osaka Prefecture University, for the loan of the specimens recorded as Lenarchus sp. LA. We are gratefull to Ms. A. OHKAWA for her help on the field collection.

\section{REFERENCES}

Ito, T., Kamei, H., Ohkawa, A., Kuhara, N. and Nishimoto, N. (1998) : Caddisfly of the Shibetsu District and the Shiretoko Pass, eastern part of Hokkaido, northern Japan. Biol. Inl. Wat., (13) : 1-17 (in Japanese with English summary).

Itou, M., Nozaki, T. and Hirama, Y. (1993) : Four limnephilid caddisflies (Trichoptera) from eastern Hokkaido, Japan, with a new record of Limnephilus diphyes McLachlan. Sylvicola, 11: 1-4 (in Japanese).

Kuwayama, S. (1924) : Trichoptera. In Iconographia Insectorum Japonicorum : 1498-1513, Hokuryukan, Tokyo (in Japanese).

Nimmo, A. P., Arefina, T. I. and Levanidova, I. M. (1997) : Limnephilidae. In Key to the insects of Russian Far East, Vol. 5, Trichoptera and Lepidoptera : 93-126. Dal'nauka, Vladivostok (in Russian).

NozAKI, T. and TANIDA, K. (1996) : The genus Limnephilus Leach (Trichoptera, Limnephilidae) in Japan. Jpn. J. Ent., 64:810-824.

Schmid, F. (1952) : Le groupe de Lenarchus MarT. (Trichopt. Limnophil.). Mitt. Schweiz. Ent. Ges., $25: 157-210$.

Schmid, F. (1955) : Contribution à l'étude des Limnophilidae (Trichoptera). Mitt. Schweiz. Ent. Ges., 28 : 1-245.

Solem, J. O. and Gullefors, B. (1996) : Trichoptera, caddisflies. In Aquatic Insects of North Europe-A taxonomic handbook, Vo. 1, Nilsson, A. N. (ed.) : 223-255. Apollo Books, Stenstrup.

TANIDA, K. (1985) : Trichoptera. In An illustrated book of aquatic insects of Japan, KaWal, T. (ed.) : 167-215. Tokai Univ. Press, Tokyo (in Japanese).

WIGGINS, G. B. (1977): Larvae of the North American caddisfly genera (Trichoptera). Univ. Toronto Press, Toronto, Buffalo and London.

WigGINs, G. B. (1996) : Trichoptera families. In An Introduction to the aquatic insects of North America (3rd. ed), MerRit, R. W. and Cummins, K. W. (eds.) : 309-349. Kendall/Hunt Pub., Iowa.

Winterbourn, M. J. (1971): The life histories and trophic relationships of the 
Trichoptera of Marion Lake, British Columbia. Can. J. Zool., 49: 623-635.

Takao NozAKI: Kanagawa Environmental Research Center, 842 NakaharaShimojuku, Hiratsuka, Kanagawa 254-0072（野崎隆夫：干 254-0072 平塚市 中原下宿 842 , 神奈川県環境科学センタ一)

Tomiko Iтo : Hokkaido Fish Hatchery, 3-373, Kita-kashiwagi, Eniwa, Hokkaido 061-1433(伊藤富子： $\bar{T}$ 061-1433 北海道恵庭市北柏木町 3-373, 北海道吉水 産尒化場)

(Received : 14 May 1998 ; Accepted : 24 August 1998)

\title{
クロズェグリトビケラ(Lenarchus fuscostramineus SCHMID) の幼虫及び蛹の記載
}

\author{
野崎隆夫・伊藤富子
}

摘 要

全北区の北部に 13 種が分布するクロズエグリトビケラ属Lenarchus は, 幼虫並びに蛹 の時期の情報が形態, 生態ともに非常にそしいグループである。日本では本属の種として クロズエグリトビケラ Lenarchus fuscostramineus ScHMID 1 種の分布が知られるが，その 幼虫及び蛹は発見されていなかった。今回，北海道内の紼流で採集された未知の幼虫を飼 育することにより, 蛹及び成虫が得られ親子関係を知ることができた。そこで，本種の幼 虫及び蛹の形態を記載するとともに，その生息環境及び食性についても述べた。なお，本 州からクロズエグリトビケラ属の幼虫として記載されたLenarchus sp. LA は, 基となっ た標本を検討した結果ホタルトビケラ属 Nothopsyche に属することが判明したので，クロ ズエグリトビケラ属の本州における記録は現時点ではなくなった。 